\title{
THE COST OF LEARNING FROM FAILURES AND MISTAKES IN PRODUCT DESIGN: REVIEWING THE LITERATURE
}

\author{
Shafqat, Ali (1); Oehmen, Josef (2); Welo, Torgeir (1); Willumsen, Pelle (2) \\ 1: Norwegian University of Science and Technology; 2: Technical University of Denmark
}

\begin{abstract}
In the design phase of product development (PD) process, most new products face significant uncertainties and risks. Uncertainty is typically associated with a lack of information, while learning is a process that acquires information. Therefore, learning fast and at low cost decreases the uncertainty and increases the efficiency of the product design phase. This paper investigates the concept of the cost of learning in PD's design phase. Reviewing the literature, we conceptualize the cost of learning and review the learning methods considering three aspects in the design phase of the PD process: (1) costs associated with learning from mistakes and failures, (2) learning methods and (3) categories of learners. This paper thus provides the conceptual foundations for future work to increase the efficiency of the PD process by reducing the cost of learning from mistakes and failures.
\end{abstract}

Keywords: Design learning, Design costing, New product development, Uncertainty, Design methods

Contact:

Shafqat, Ali

Norwegian University of Science and Technology

Mechanical and Industrial Engineering

Norway

ali.shafqat@ntnu.no

Cite this article: Shafqat, A., Oehmen, J., Welo, T., Willumsen, P. (2019) 'The Cost of Learning from Failures and Mistakes in Product Design: Reviewing the Literature', in Proceedings of the 22nd International Conference on Engineering Design (ICED19), Delft, The Netherlands, 5-8 August 2019. DOI:10.1017/dsi.2019.171 


\section{INTRODUCTION}

Today's organisations strive to achieve technological advancements and growth. To have an advantage over competitors, organisations must innovate new products or improve existing products. In this regard, companies must strive to optimise cost, quality and lead time (Oehmen et al., 2010, Chauhan et al., 2017).

At the same time, new product development (NPD) projects are becoming more complex as they become more unique and as more requirements change due to dynamics in the market. Hence, the NPD process faces significant risks, including technical risk, financial risk, collaboration risk, regulatory risk, schedule risk and market risk (Awny 2006, Unger and Eppinger 2009, Wu and Wu 2014). Moreover, in the early phases of NPD projects, there are more risks and uncertainties (Lough et al., 2009) due to lack of information. The literature demonstrates that current product development methods are not fully capable of addressing these additional challenges (Oehmen et al., 2014, Schuh et al. 2017). Therefore, many NPD projects fail during their development processes or soon after they are in the market (Barczak et al., 2009).

To solve design problems, NPD teams learn from failures and mistakes (Drupsteen and Guldenmund 2014, Kolb 2014). To improve current and future projects, teams and individuals use the learning outcomes of efforts to solve design problems in the design phase. As a result, the costs of learning related to solving issues in NPD are the utilised resources, such as time and money, and sometimes product failure. Therefore, the overall product development process becomes expensive and less productive.

The success of NPD projects directly affects the growth and profitability of the organisation. Yet the success rate of the new products is disappointing. One study reveals that only $15 \%$ of new ideas for products and around $60 \%$ of NPD projects achieve commercial success in the market (Barczak et al., 2009). Another study (Gourville 2006) shows that the failure rate of new products can reach $90 \%$. In the majority of the cases, NPD projects turned out to be costly, and failure was too expensive for organisations in terms of input resources.

There are multiple studies on the lessons learned from mistakes (Schindler and Eppler 2003, Stosic et al., 2016, McClory et al., 2017); however, to our knowledge, there are few literature reviews on the "cost of learning" and "learning methods" in product design. Therefore, we address the identified literature gap regarding the "cost of learning" in the engineering design phase of the NPD process. This literature review will contribute to a future research agenda for understanding the role of risk mitigation in minimizing the cost of learning and thus the cost of product development. In this literature review, we ask the following research questions:

- What are the learning methods in product design?

- How can we describe the cost of learning in product design?

The corporate world primarily uses the term "learning" from an organisational perspective (Senge 1991). There is also a trend in the academic community to study learning in connection to NPD (Lynn et al., 1996, Lynn et al., 2003, Akgün et al., 2006, Cui et al., 2014, Un and Rodríguez 2018). We take the definition of learning as "processes of information or knowledge acquisition, distribution, interpretation and storage" (Schulze et al., 2013). The product design phase plays the main role in defining the physical form and function of the product. The design phase includes various activities from, for example, the areas of industrial design (user interface, aesthetics, and ergonomics) and engineering design (mechanical, electrical, software, etc.) (Ulrich and Eppinger 2015). This paper focuses on learning in engineering design teams. Therefore, we limit the scope of this paper to the context of learning in engineering design.

This paper contributes to the existing research on this subject in two ways. First, this paper provides an overview of the types of learners, learning methods and the costs associated with learning in the NPD design phase. Second, this paper contributes to the understanding of the link between the cost of learning and learning methods. This paper provides a conceptual framework for future research aimed at integrating the three separate streams of research: organisational learning, risk management and NPD. 
The structure of the remaining paper is as follows. Section 2 describes the research methodology and details about the literature search and analysis. Section 3 provides an overview of the results of the literature search. Section 4 discusses the results, in order to improve the NPD process from a learning perspective. Section 5 concludes the discussion and briefly explains the potential for future research.

\section{METHOD}

To create an overview of the literature, we used the Scopus and Science Direct databases. Our searches focused on the titles, keywords and abstracts of the peer-reviewed papers without limiting the search to specific dates of publication. We reviewed English language papers only and used Boolean operators (OR and AND) in the search strings. The following search strings were used: ("product development process" AND learning), ("product design" AND "learning cost"), ("product development process" AND "learning" AND "cost") and ("innovation" AND "learning cost"). We excluded the fields of "nursing", "health care" and "medicine". We did not focus on additional searches for topics about knowledge management and general learning in projects. The initial searches with the aforementioned search strings in Scopus (339) and Science Direct (273) produced 612 references. The initial scanning of the titles produced 49 relevant research articles for closer review. After scanning the abstracts and the introduction and conclusion sections, we excluded 30 papers since these papers primarily addressed organisational learning and knowledge management in NPD projects. We studied the remaining 21 articles in detail and identified nine additional articles after backward referencing. To answer the research questions in this paper, we therefore reviewed 30 articles in total.

\section{LEARNING IN PRODUCT DEVELOPMENT PROCESS}

In connection with the topic of learning in the NPD process, we adopt the definitions of the singleloop and double-loop learning theories by (Argyris and Schon 1974). According to (Argyris and Schön 1997), when the error detection and correction process permits the organisation to follow its present policies, this process is called single-loop learning. Double-loop learning takes place when the error detection and correction process questions and modifies the organisation's underlying policies and objectives. The design teams learn from failures and mistakes and improve the design. We can describe single-loop and double-loop learning with an example from NPD projects. In the detailed design phase of NPD projects, the design teams make efforts to achieve the design requirements. In this design process, designers face problems to achieve the set design goals. To solve the design problems, designers change their approach and acquire the appropriate knowledge. This is the example of a single-loop learning process in an NPD context. Another example of what is meant by doubleloop learning is to change the set requirements of the NPD project by taking feedback from design and marketing teams. Hence, the management learns from mistakes and learn in order to improve the next NPD projects.

\subsection{Costs of learning}

Kessler et al. (2000) studied 75 NPD projects to investigate the influence of technology sourcing strategies on innovation speed, development cost and competitive advantage. The results of the study demonstrate that more technology sourcing lowers competitive success and increases development costs. Outsourcing in the technology development phase of an NPD project significantly increases project completion time. Therefore, we can conclude that learning through outsourcing in design teams can increase the development time and cost of NPD projects. Smite and van Solingen (2016) conducted a study on software-based product development scenarios. They conclude in their study that the cost of learning due to outsourcing outside the company was more than the hourly cost of in-house learning. In the end, they find it less expensive to learn within the company. Therefore, we can infer that the cost associated with learning from outsourcing is more than in-house learning. Lilly and Porter (2003) argue that improvement reviews of the NPD process can be a step to enhance learning in NPD process. These reviews serve as inputs that help teams prioritise the best-suited learning agenda for solving design problems. Therefore, design teams can use lessons learned from previous product development projects as an input that helps them identify the design issues with greater impact on project costs. Therefore, the quicker the response to the problems identified in the review process, the lower the cost of learning. We can conclude that (lead) time is another factor associated with the cost 
of learning. Likewise, Postrel (2002) claims that the learning tasks with previous knowledge have lower learning cost as compared to completely new learning tasks.

Del Río et al. (2014) point out that virtual experiments, such as CAD models in the design phase, can reduce the development time and cost of learning in the product development process. Thus, development time and money can be identified as the cost of learning in the design phase of NPD projects. Similarly, Henshall et al. (2017) identify design rework as a cost factor that engineering design teams can reduce with learning interventions that develop the skills of the engineering teams. Therefore, we can identify the cost of design rework as one type of learning cost.

Drupsteen and Guldenmund (2014) conducted a literature review and defined learning from incidents and accidents based on the results of the events that have occurred. Therefore, we can conclude that the costs of learning in these scenarios are the failures of the designs or the mistakes in the design phase.

The evidence presented in this section suggests that the cost of learning can be classified as time and money. The results from current section are discussed in section 4 .

\subsection{Categories of learners}

Saban et al. (2000) categorise learners in the product development process as learners in level 1 and level 2. Level 1 participants, in single-loop and double-loop learning, are typically design teams and designers. Level 2 learners are at a strategic level and are the ones that establish business goals.

Observations and investigations in the field of organisational learning have revealed that teams are the fundamental source of learning in organisations (Senge 1991, Leonard-Barton 1995, Nonaka and Takeuchi 1996). Leifer and Steinert (2011) also agree in their study that product development teams learn in the design and development process. Most of the papers cited by Leifer and Steinert (2011) categorise learners in the product development process as teams and individuals. Overall, the evidence presented in this section suggests that teams and individuals are the two main categories of the learners in engineering product development.

\subsection{Measures of learning in the product development process}

To measure the learning and cost associated with repetitive tasks, Anzanello and Fogliatto (2011) review the literature on learning curves. The concept of learning curves can also be used in the product development process to measure the learning capability of design teams and individuals (Anzanello and Fogliatto 2011). In contrast, as product development is not a repetitive task, it is difficult to measure the learning capability of design teams and individual designers by implementing the learning curve method. There are many factors (e.g., prior experience and task complexity) that affect the learning capabilities of individuals and design teams (Pananiswami and Bishop 1991, Nembhard and Uzumeri 2000b, Nembhard and Uzumeri 2000a). The fields of design learning and design education can be an inspiration for the measurement of learning in engineering design teams. Boylan and Demack (2018) argue that professional learning can be assessed in innovative projects by measuring the improvements in outcomes and assessing the extent to which professional learning occurs. Denson et al. (2015) argue that the Consensual Assessment Technique can be used to measure creativity in engineering design. This method can possibly be an inspiration for measuring the creativity of design teams in solving design issues. They represent web-based adaption of the Consensual Assessment Technique for the evaluation of student projects. The students developed engineering projects during a week-long engineering camp.

\subsection{Learning methods in the product development process}

Dalmaz et al. (2015) review learning methods from an NPD perspective. They categorise learning methods as either formal or informal methods of learning. McKee (1992) reviews the literature on the organisational learning approach to product development. He relates three learning levels to innovation. Specifically, he relates single-loop learning to incremental innovation, double loop learning to discontinuous innovation and meta-learning (i.e., how to fail intelligently) to institutionalised innovation. Single-loop and double-loop learning occur in specific product development projects and meta-learning helps higher management in learning from experiences in innovation projects. Similarly, Leifer and Steinert (2011) propose that learning in the product development process occur in formal and informal ways. Based on prior work, they identify three 
learning loops in the product development process. Learning loop one is based on explicit knowledge and it brings product development teams into the formal structure of the organisation. In loop one, the aim of the learning is to retain project knowledge. This loop falls into the category of formal learning. In loop two, learning occurs during exchanges between design teams and coaches. Learning loop two is categorised as an informal way of learning. The third learning loop is also an informal way of learning, and team members learn from each other and prior teams' experiences.

Yuan Fu et al. (2006) identify the knowledge required for teams to make decisions in the product development process, such as market knowledge, human knowledge, technological knowledge and procedural knowledge. Therefore, we can say that knowledge acquisition is an essential part of the learning process in which the appropriate knowledge is acquired and processed. Cui et al. (2014) propose that new information generated during the NPD process is a source of learning. They identify this information acquisition as the learning zone in NPD. The teams in NPD learn from new knowledge generated in the innovation process. Therefore, we categorise this learning method as "learning by doing".

Drupsteen and Guldenmund (2014) review the literature on safety and define learning from incidents within organisations. They compare learning from incidents with organisational learning. This learning method is another way of learning in the product design phase that can be referred to as "learning from mistakes and incidents". Their study also demonstrates that only high impact incidents are used for learning and many opportunities to learn from small incidents are missed due to lack of reporting.

Erichsen et al. (2016) propose a model of four prototyping categories to learn internally and externally in the product development process. They use two case studies from the automotive industry and propose prototypes as a method of learning in the product development process, both internally and externally.

Un and Rodríguez (2018) analyse the influence of research and development outsourcing on product innovation. Outsourcing is another way of learning in NPD projects. Lynn et al. (2003) propose the accelerated learning concept in new product development teams. They argue that fast learning enables product development teams to introduce new products into the market quickly, which can increase the product success rate. They suggest that vision clarity, knowledge gained from customers and competitors, past product reviews and aggressive deadlines can be the ways of learning in the product development process. Likewise, Henshall et al. (2017) argue that learning can enhance the efficiency of the product development process and reduce the cost of design rework. They suggest that efficiency of the product development process can be enhance by defining learning intervention aimed at developing skills in senior engineering management. They propose lectures, training and group work as learning strategies or methods in the product development process.

Henshall et al. (2017) developed a model of learning cycles in the NPD process. They developed three learning methods: (1) "learning by using," which is based on customers' experiences after using the product, (2) "learning by doing," which occurs as the firm manufactures a greater volume of the product and (3) "learning by failures," which takes place as managers identify failure patterns and weak links in the organisation by launching successive generations of the product into market.

D'Este et al. (2017) identify two types of learning mechanisms in exploratory R\&D, which they label as "learning from experience" and "inferential-based learning". To reduce the failure rate of NPD projects, it might be possible for design teams to use learning opportunities.

In summary, these results demonstrate that product development teams learn about solutions to design problems using various learning methods. The learning methods identified in the literature are summarised in the next section of this paper.

\section{DISCUSSION}

Our analysis of the literature demonstrates that the cost of learning due to failures and mistakes in product development processes is not well defined. In reviewing the literature, we found insufficient data (Un and Rodríguez 2018) on the relation between cost and learning in the product development process. The results of this study indicate that the cost of learning in product development depends on the learners and learning methods (e.g., learning through prototyping or outsourcing). Another important finding of this review is that despite the number of papers written on the subject of learning 
in the product development process, the initial reviewed papers tend to be more focused on learning in all NPD phases instead of learning in the design phase.

The organisational learning theory proposed by Argyris and Schon (1974) also agrees that individuals and teams are the sources of learning in organisations. There exists another categorisation of learners as level 1 and level 2 learners that is based on the organisational learning theories of single-loop learning and double-loop learning. The results of this study confirm that individuals and teams are the basic categories of learners in product development processes (Leonard-Barton 1995, Nonaka and Takeuchi 1996, Leifer and Steinert 2011).

\section{Table 1. Learning methods}

\begin{tabular}{|c|c|c|}
\hline Learning Method & $\begin{array}{c}\text { Categories of } \\
\text { learning methods }\end{array}$ & Reference \\
\hline $\begin{array}{l}\text { Learning through knowledge } \\
\text { acquisition, training and } \\
\text { lectures }\end{array}$ & Formal & $\begin{array}{r}\text { (Yuan Fu, Ping Chui, \& } \\
\text { Helander, 2006), (Henshall et al., } \\
\text { 2017) }\end{array}$ \\
\hline Learn by doing & Formal & $\begin{array}{r}\text { (Cui et al., 2014), (Henshall et } \\
\text { al., 2017) }\end{array}$ \\
\hline $\begin{array}{l}\text { Learning from incidents and } \\
\text { failures }\end{array}$ & Formal/Informal & $\begin{array}{l}\text { (Drupsteen \& Guldenmund, } \\
\text { 2014), (Henshall et al., 2017) }\end{array}$ \\
\hline Prototyping and experiments & Formal & (Erichsen et al., 2016) \\
\hline $\begin{array}{l}\text { Learning from teammates and } \\
\text { coaches }\end{array}$ & Informal & (Leifer \& Steinert, 2011) \\
\hline Outsourcing & Formal & (Un \& Rodríguez, 2018) \\
\hline $\begin{array}{l}\text { Past product reviews, } \\
\text { customers }\end{array}$ & Formal & (Lynn et al., 2003) \\
\hline
\end{tabular}

To solve design issues, design teams face unique challenges and situations in which they learn. The literature to date makes little reference to the question of how to measure learning in engineering design teams. The manufacturing industry primarily uses learning curves to measure learning in repetitive tasks. To measure learning in the product design phase, it is challenging to implement the learning curve methodology because of the non-repetitive nature of the tasks, complexity of the tasks and the learning capability of individuals and design teams. However, Anzanello and Fogliatto (2011) argue that by using the learning curve methodology, design teams can measure the learning involved in the development of products that are similar in terms of configuration. We suggest that the learning ability of design teams can be linked to the time between the detection of the design problem and the time needed to solve the identified problem. However, this time also depends on the complexity of the design problem and the previous experience of the designers. The expected learning time needed to solve the design problems can be longer if the design team does not have previous experience in solving similar design problems detected in the design process.

Table 1 addresses the first research question and illustrates that different learning methods do exist in product design. When focusing on the design phase, we observe that design teams learn in formal and informal ways to find the solutions to design problems. Therefore, we divide the learning methods into two categories, formal and informal, as illustrated in Table 1. The identified methods are suitable in certain situations; for example, when the product is unique and there are market risks, the suitable method for learning about market needs might be "prototyping". In contrast, NPD projects with low market and technical risks might not need prototyping. When the product design has similarities with other product development projects, the past product review can be a suitable method for learning. Therefore, it can be possible to assume that the selection of a suitable learning method can affect the cost of learning from an engineering design perspective.

Table 2, which relates to the second research question, illustrates that the cost of learning can be divided into two categories: time and money. The literature review also indicates that the cost of learning depends on the type of learning task (e.g., new tasks or tasks based on previous knowledge). There is a link between both types of costs of learning (time and money); for example, when the launching time of the product is of primary importance, money becomes the second priority and time is considered as the cost of learning. When NPD projects have limited resources and flexibility in terms of time to market the product, money or development costs becomes the cost of learning. Early 
in the design process, exploring and prioritising difficult learning tasks can reduce the cost of learning. Similarly, using prototypes and design iterations to acquire customer feedback in the early stages of the product development process can reduce the cost of learning. Therefore, in our opinion, it is possible to learn proactively in the early stages of the product design process by foreseeing potential design problems. By reviewing the literature on the cost of learning due to failures and mistakes in the product development process, we contribute to the knowledge about the cost of learning from mistakes and failures in NPD projects and learning methods. This will help to identify possible explanations for inefficiencies and high costs of learning in the NPD process.

Table 2. Categories of the cost of learning

\begin{tabular}{|l|c|r|}
\hline Cost of learning & Category & Reference \\
\hline $\begin{array}{l}\text { Time overrun due } \\
\text { to outsourcing } \\
\text { learning }\end{array}$ & Time & (Kessler et al., 2000), (Postrel, 2002) \\
\hline $\begin{array}{l}\text { Design failure, } \\
\text { Design rework }\end{array}$ & Money & (Del Río et al., 2014), (Lilly \& \\
& & Porter, 2003), (Smite and van \\
& & Solingen 2016), (Henshall et al., \\
& & 2017), (Drupsteen \& Guldenmund, \\
& & 2014) \\
\hline
\end{tabular}

This literature review also provides the theoretical foundations for further research on increasing the efficiency of the product development process by reducing the cost of learning through risk management. The literature review is limited to a selection of peer-reviewed papers only, whereas there are books that cover different aspects of learning in the product development process.

\section{CONCLUSION}

The design phase of the product development process faces unique problems due to uncertainties and risks. Timely information and learning about design problems and solutions tend to reduce the uncertainties and mitigate risks. In many situations, learning from mistakes and incorrect decisions in the design phase is costly. There is a range of studies on individual, team and organisational learning. However, there is a gap in the literature review on the cost of learning in the design phase of the engineering product development process.

The cost of learning is not well defined in the engineering design phase of the product development phase. This paper has defined the cost of learning in the design phase as time and money. Time as the cost of learning is further categorised as time overrun due to outsourcing the learning. Money as the cost of learning is subcategorised into design failure and design rework. The paper has also identified that generally, the categories of learners in the product design phase are individual product designers and design teams. Reviewing the literature, we mainly categorised the learning methods in the design phase into formal and informal learning methods. Learning methods such as learning by doing, prototyping, outsourcing, consulting past product reviews and learning through training and lectures are included in the formal learning methods category. Learning from incidents is included in the informal learning methods category. We find in the literature that the selection of learning methods is claimed to affect the cost of learning. One of the more significant findings emerging from this paper is that to reduce learning costs, risk analysis can be used in the product design phase. The risk analysis process can identify the design problems and design engineers can choose suitable learning strategies for solving design problems.

These findings contribute in several ways to our understanding of the cost of learning in the product design phase. The most important limitation is the fact that we review the literature in relation to engineering knowledge-based physical product development projects. We are not focusing on software- and medicine-related product development projects. Despite this limitation, this paper could add to the understanding of different aspects of learning in the product design phase. 


\section{REFERENCES}

Akgün, A.E., Lynn, G.S. and Y1lmaz, C. (2006), "Learning process in new product development teams and effects on product success: A socio-cognitive perspective", Industrial Marketing Management, Vol. 35 No. 2, pp. 210-224. http://dx.doi.org/10.1016/j.indmarman.2005.02.005

Anzanello, M.J. and Fogliatto, F.S. (2011), "Learning curve models and applications: Literature review and research directions", International Journal of Industrial Ergonomics, Vol. 41 No. 5, pp. 573-583. https://doi.org/10.1016/j.ergon.2011.05.001

Argyris, C. (1977), "Double loop learning in organizations”, Harvard Business Review, Vol. 55 No. 5 , pp. $115-125$.

Argyris, C. and Schon, D.A. (1974), Theory in practice: Increasing professional effectiveness, Jossey-Bass

Argyris, C. and Schön, D.A. (1997), "Organizational learning: A theory of action perspective", Reis, No. 77/78, pp. 345-348. https://doi.org/10.2307/40183951

Awny, M.M. (2006), "Product development strategy: a perspective of enterprises”, International Journal of Product Development, Vol. 3 No. 2, pp. 143-151. https://doi.org/10.1504/ijpd.2006.009362

Barczak, G., Griffin, A. and Kahn, K.B. (2009), "Perspective: trends and drivers of success in NPD practices: results of the 2003 PDMA best practices study", Journal of Product Innovation Management, Vol. 26 No. 1, pp. 3-23. https://doi.org/10.1111/j.1540-5885.2009.00331.x

Boylan, M. and Demack, S. (2018), "Innovation, evaluation design and typologies of professional learning”, Educational Research, Vol. 60 No. 3, pp. 336-356. https://doi.org/10.1080/00131881.2018.1493352

Chauhan, A.S., Yadav, O.P., Soni, G. and Jain, R. (2017), “A holistic approach to manage risks in NPD process", in Reliability and Maintainability Symposium (RAMS), 2017 Annual, IEEE, pp. 1-5. https://doi.org/10.1109/ram.2017.7889796

Cooper, L.P. (2003), “A research agenda to reduce risk in new product development through knowledge management: a practitioner perspective", Journal of Engineering and Technology Management, Vol. 20 No. 1-2, pp. 117-140. https://doi.org/10.1016/s0923-4748(03)00007-9

Cui, A.S., Chan, K. and Calantone, R. (2014), "The Learning Zone in New Product Development", IEEE transactions on engineering management, Vol. 61 No. 4, pp. 690-701. https://doi.org/10.1109/tem.2014.2331757

D’Este, P., Marzucchi, A. and Rentocchini, F. (2017), "Exploring and yet failing less: learning from past and current exploration in R\&D”, Industrial and Corporate Change, Vol. 27 No. 3, pp. 525-553. https://doi.org/10.1093/icc/dtx044

Dalmaz, A., Possamai, O. and Armstrong, A.J. (2015), "Methods of Learning in Product Development Contexts", American Journal of Industrial and Business Management, Vol. 05 No. 11, pp. 699-704. https://doi.org/10.4236/ajibm.2015.511069

Del Río, L., Barrio, S., Izcara, J. and Aranaga, S. (2014), "Development of optimized vacuum interrupters through virtual experimentation", in Discharges and Electrical Insulation in Vacuum (ISDEIV), 2014 International Symposium on, IEEE, pp. 321-323.

Denson, C.D., Buelin, J.K., Lammi, M.D. and D’Amico, S. (2015), “Developing Instrumentation for Assessing Creativity in Engineering Design”, Journal of Technology Education, Vol. 27 No. 1, pp. 23-40. https://doi.org/10.1109/deiv.2014.6961684

Drupsteen, L. and Guldenmund, F.W. (2014), "What is learning? A review of the safety literature to define learning from incidents, accidents and disasters", Journal of Contingencies and Crisis Management, Vol. 22 No. 2, pp. 81-96. https://doi.org/10.1111/1468-5973.12039

Erichsen, J.A., Pedersen, A.L., Steinert, M. and Welo, T. (2016), "Using prototypes to leverage knowledge in product development: Examples from the automotive industry", in Systems Conference (SysCon), 2016 Annual IEEE, IEEE, pp. 1-6. https://doi.org/10.1109/syscon.2016.7490586

Gourville, J.T. (2006), "Eager sellers \& stony buyers”, Harvard Business Review, Vol. 84 No. 6, pp. 98-106.

Henshall, E., Campean, F. and Rutter, B. (2017), “A systems approach to the development of enhanced learning for engineering systems design analysis”, Procedia CIRP, Vol. 60, pp. 530-535. https://doi.org/10.1016/j.procir.2017.01.020

Kessler, E.H., Bierly, P.E. and Gopalakrishnan, S. (2000), "Internal vs. external learning in new product development: effects on speed, costs and competitive advantage", R\&d Management, Vol. 30 No. 3, pp. 213-224. https://doi.org/10.1111/1467-9310.00172

Kolb, D.A. (2014), Experiential learning: Experience as the source of learning and development, FT press

Leifer, L.J. and Steinert, M. (2011), "Dancing with ambiguity: Causality behavior, design thinking, and tripleloop-learning”, Information Knowledge Systems Management, Vol. 10 No. 1-4, pp. 151-173. https://doi.org/10.1007/978-3-319-01056-4_11

Leonard-Barton, D. (1995), "Wellsprings of knowledge: Building and sustaining the sources of innovation". Long Range Planning, Vol. 29 No. 6, p. 909. https://doi.org/10.1016/s0024-6301(97)82842-7 
Lilly, B. and Porter, T. (2003), "Improvement reviews in new product development", R\&d Management, Vol. 33 No. 3, pp. 285-296. https://doi.org/10.1111/1467-9310.00298

Lough, K.G., Stone, R. and Tumer, I.Y. (2009), "The risk in early design method", Journal of Engineering Design, Vol. 20 No. 2, pp. 155-173. https://doi.org/10.1080/09544820701684271

Lynn, G.S., Akgün, A.E. and Keskin, H. (2003), “Accelerated learning in new product development teams", European Journal of Innovation Management, Vol. 6 No. 4, pp. 201-212. https://doi.org/10.1108/14601060310500922

Lynn, G.S., Morone, J.G. and Paulson, A.S. (1996), "Marketing and Discontinuous Innovation: The Probe and Learn Process", California management review, Vol. 38 No. 3, pp. 8-37. https://doi.org/10.2307/41165841

McClory, S., Read, M. and Labib, A. (2017), “Conceptualising the lessons-learned process in project management: Towards a triple-loop learning framework", International Journal of Project Management, Vol. 35 No. 7, pp. 1322-1335. https://doi.org/10.1016/j.ijproman.2017.05.006

McKee, D. (1992), “An organizational learning approach to product innovation”, Journal of Product Innovation Management: An International Publication Of The Product Development \& Management Association, Vol. 9 No. 3, pp. 232-245. https://doi.org/10.1016/0737-6782(92)90033-9

Nembhard, D.A. and Uzumeri, M.V. (2000a), "Experiential learning and forgetting for manual and cognitive tasks", International Journal of Industrial Ergonomics, Vol. 25 No. 4, pp. 315-326. https://doi.org/10.1016/s0169-8141(99)00021-9

Nembhard, D.A. and Uzumeri, M.V. (2000b), "An individual-based description of learning within an organization”, IEEE transactions on engineering management, Vol. 47 No. 3, pp. 370-378. https://doi.org/10.1109/17.865905

Nonaka, I. and Takeuchi, H. (1996), “The knowledge-creating company: How Japanese companies create the dynamics of innovation”, Long range planning, Vol. 4 No. 29, p. 592. https://doi.org/10.1016/s0048-7333(97)80234-X

Oehmen, J., Ben-Daya, M., Seering, W. and Al-Salamah, M. (2010), "Risk Management in Product Design: Current State, Conceptual Model and Future Research”, No. 44090, pp. 1033-1041. https://doi.org/10.1115/detc2010-28539

Oehmen, J., Olechowski, A., Robert Kenley, C. and Ben-Daya, M. (2014), "Analysis of the effect of risk management practices on the performance of new product development programs", Technovation, Vol. 34 No. 8, pp. 441-453. https://doi.org/10.1016/j.technovation.2013.12.005

Pananiswami, S. and Bishop, R.C. (1991), "Behavioral implications of the learning curve for production capacity analysis", International Journal of Production Economics, Vol. 24 No. 1-2, pp. 157-163. https://doi.org/10.1016/0925-5273(91)90162-m

Postrel, S. (2002), "Islands of shared knowledge: Specialization and mutual understanding in problemsolving teams", Organization science, Vol. 13 No. 3, pp. 303-320. https://doi.org/10.1287/orsc.13.3.303.2773

Saban, K., Lanasa, J., Lackman, C. and Peace, G. (2000), “Organizational learning: a critical component to new product development”, Journal of Product \& Brand Management, Vol. 9 No. 2, pp. 99-119. https://doi.org/10.1016/s0737-6782(00)00085-0

Schindler, M. and Eppler, M.J. (2003), "Harvesting project knowledge: a review of project learning methods and success factors", International Journal of Project Management, Vol. 21 No. 3, pp. 219-228. https://doi.org/10.1016/s0263-7863(02)00096-0

Schuh, G., Gartzen, T., Soucy-Bouchard, S. and Basse, F. (2017), "Enabling Agility in Product Development through an Adaptive Engineering Change Management", Procedia CIRP, Vol. 63, pp. 342-347. https://doi.org/10.1016/j.procir.2017.03.106

Schulze, A., Schmitt, P., Heinzen, M., Mayrl, P., Heller, D. and Boutellier, R. (2013), "Exploring the 4I framework of organisational learning in product development: value stream mapping as a facilitator", International Journal of Computer Integrated Manufacturing, Vol. 26 No. 12, pp. 1136-1150. https://doi.org/10.1080/0951192x.2011.608724

Senge, P.M. (1991), "The fifth discipline, the art and practice of the learning organization", Performance+ Instruction, Vol. 30 No. 5, pp. 37-37. https://doi.org/10.1002/pfi.4170300510

Smite, D. and van Solingen, R. (2016), "What's the True Hourly Cost of Offshoring?", IEEE Software, Vol. 33 No. 5, pp. 60-70. https://doi.org/10.1109/ms.2015.82

Stosic, B., Mihic, M., Milutinovic, R. and Isljamovic, S. (2017), "Risk identification in product innovation projects: new perspectives and lessons learned", Technology Analysis \& Strategic Management, Vol. 29 No. 2, pp. 133-148. https://doi.org/10.1080/09537325.2016.1210121

Ulrich, K. and Eppinger, S. (2015), Product Design and Development, McGraw-Hill Education https://books.google.no/books?id=UGrcoQEACAAJ

Un, C.A. and Rodríguez, A. (2018), "Learning from R\&D outsourcing vs. learning by R\&D outsourcing", Technovation, 72-73, pp. 24-33. https://doi.org/10.1016/j.technovation.2017.12.003 
Unger, D.W. and Eppinger, S.D. (2009), “Comparing product development processes and managing risk”, International Journal of Product Development, Vol. 8 No. 4. https://doi.org/10.1504/ijpd.2009.025253

$\mathrm{Wu}, \mathrm{J}$. and Wu, Z. (2014), "Integrated risk management and product innovation in China: The moderating role of board of directors", Technovation, Vol. 34 No. 8, pp. 466-476. https://doi.org/10.1016/j.technovation.2013.11.006

Yuan Fu, Q., Ping Chui, Y. and Helander, M. G. (2006), "Knowledge identification and management in product design”, Journal of Knowledge Management, Vol. 10 No. 6, pp. 50-63.

https://doi.org/10.1108/13673270610709215 